\title{
Ascidians (Urochordata: Ascidiacea) from Arraial do Cabo, Rio de Janeiro, Brazil ${ }^{1}$
}

\author{
Rosana M. da Rocha² \& Luciana V. G. Costa ${ }^{3}$
}

1. Contribution 1499 of the Departamento de Zoologia, Universidade Federal do Paraná (UFPR).

2. Universidade Federal do Paraná, Departamento de Zoologia, Caixa Postal 19020, 81531-980, Curitiba, Paraná, Brazil. (rmrocha@ufpr.br)

3. Universidade Federal do Rio de Janeiro, Prédio do CCS, Laboratório de Bentos, Av. Pau Brasil, 211 B1. A, sl. 089, Ilha do Fundão, 21941-590, Rio de Janeiro, Brazil.

\begin{abstract}
Simple and colonial ascidians were collected at different depths at Arraial do Cabo, Rio de Janeiro, between 2000 and 2003. The collection here presented includes representatives of the families Clavelinidae (Clavelina oblonga), Polycitoridae (Cystodytes dellechiajei), Polyclinidae (Polyclinum constellatum and Polyclinum molle sp. nov.), Holozoidae (Distaplia bermudensis), Ascidiidae (Ascidia sydneiensis and Phallusia nigra), Styelidae (Botrylloides giganteum, Botrylloides nigrum, Symplegma brakenhielmi, Symplegma rubra, Polyandrocarpa anguinea, Eusynstyela floridana, Eusynstyela tincta and Styela plicata), Pyuridae (Herdmania pallida and Microcosmus exasperatus). Didemnids were also collected in the area but were not considered here. Of the 17 species found, one (Polyclinum molle sp. nov.) is a new species in the family Polyclinidae and the others are all species with tropical distribution.
\end{abstract}

KEYWORDS. Ascidians, tunicates, taxonomy, Brazil, Rio de Janeiro.

RESUMO. Ascídias (Urochordata: Ascidiacea) do Arraial do Cabo, Rio de Janeiro, Brasil. Ascídias simples e coloniais foram coletadas em diferentes profundidades em Arraial do Cabo, Rio de Janeiro, entre 2000 e 2003. A coleção aqui apresentada inclui representantes das famílias Clavelinidae (Clavelina oblonga), Polycitoridae (Cystodytes dellechiajei), Polyclinidae (Polyclinum constellatum e Polyclinum molle sp. nov.), Holozoidae (Distaplia bermudensis), Ascidiidae (Ascidia sydneiensis e Phallusia nigra), Styelidae (Botrylloides giganteum, Botrylloides nigrum, Symplegma brakenhielmi, Symplegma rubra, Polyandrocarpa anguinea, Eusynstyela floridana, Eusynstyela tincta e Styela plicata), Pyuridae (Herdmania pallida e Microcosmus exasperatus). Espécimes de Didemnidae também foram coletados na região, mas não serão reportados neste trabalho. Entre as 17 espécies encontradas, uma (Polyclinum molle sp. nov.) é uma nova espécie da família Polyclinidae e todas as outras apresentam distribuição tropical.

PALAVRAS-CHAVE. Ascídias, tunicados, taxonomia, Brasil, Rio de Janeiro.

While the Brazilian coast is quite extensive, the knowledge of ascidian fauna (Urochordata: Ascidiacea) is very limited and comprises about 100 registered species (Rodrigues et al., 1999). São Paulo is the only region reasonably well-known in the southeast, with several registered newly and described species (VAN NAME, 1945; BJÖRNBERG, 1956; Millar, 1958; Rodrigues, 1962, 1977; Rodrigues \& Rocha, 1993; RochA \& MonNIOT, 1993, 1995; RodRIGUES et al., 1998). For the state of Rio de Janeiro there are only the records mentioned by CostA (1969 a-f), whose described species have never been deposited in a museum collection. Also, many of those records are debatable because the descriptions were very short, figures were the same as in VAN NAME's (1945) monography and the species have never been found again in that region, even though collections were made at the same localities (M. Simões, pers. comm.). Two other important recent studies of ascidians from Rio de Janeiro are regrettably still in the form of unpublished theses. Here we begin filling this gap by presenting an inventory of the ascidian species found at Arraial do Cabo, Rio de Janeiro.

\section{MATERIAL AND METHODS}

Ascidians were collected from rocky substrates at Arraial do Cabo from 2000 to 2003 (fig. 1). This is an area of marine upwelling, which occurs mainly between November and March (VALENTIN, 1994) and is associated with an increased abundance of the fauna (CASTRO et al., 1995; Godoy \& Coutinho, 2002), besides influencing species composition, both in areas with direct and indirect influence of the upwelling (CASTRO et al., 1995).

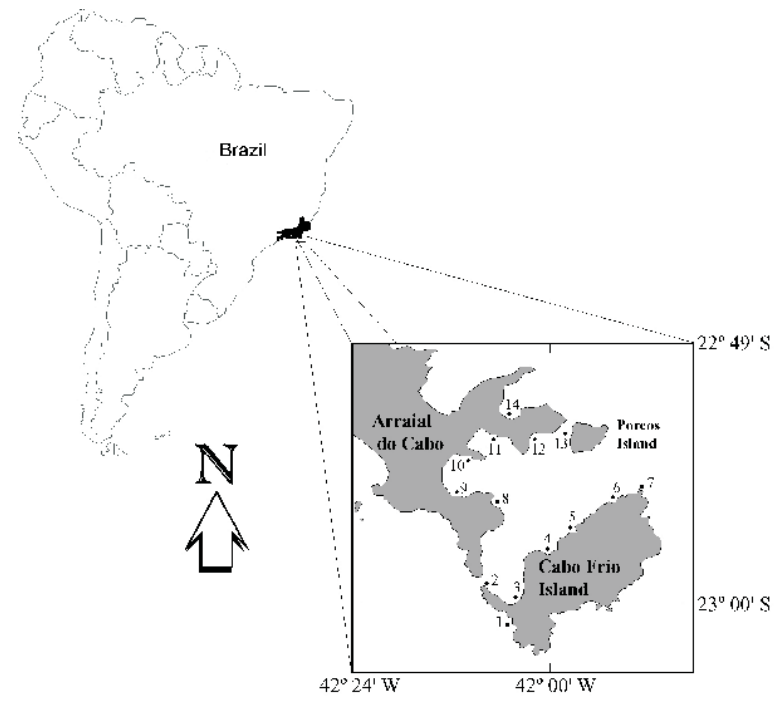

Fig. 1. Sites where ascidians were collected in Arraial do Cabo region, RJ. 1, Saco dos Ingleses; 2, Boqueirão; 3, Praia do Farol; 4, Maramutá; 5, Pedra Vermelha; 6, Saco do Anequim; 7, Ponta Leste; 8, Saco do Gato; 9, Praia dos Anjos; 10, Praia dos Anjos (Harbor); 11, Praia do Forno; 12, Saco do Cardeiro; 13, Ilha dos Porcos; 14, Saco do Cherne. 
Ascidians were collected by SCUBA diving at depths of 0.5 to $12 \mathrm{~m}$. Collections included the substrate when possible (algae or bivalve shells) or samples were scraped from substrates with spatulas (simple ascidians) or with razor-blades (colonial ascidians). Samples were placed in plastic bags and anesthetized with menthol crystals for two hours, after which they were fixed in $10 \%$ seawater formalin.

Most of the collected species are well known and so a few vouchers of each species were deposited in the collection of Ascidiacea of the Departamento de Zoologia, Universidade Federal do Paraná (DZUP). The holotype of Polyclinum molle was deposited at Museu de Zoologia, Universidade de São Paulo (MZUSP).

\section{RESULTS}

Seventeen species, not including Didemnidae, were found and are described below.

\section{Clavelinidae Forbes \& Hanley, 1848}

\section{Clavelina oblonga Herdman, 1880}

Very common along the southeastern Brazilian coast, found in shallow waters on vertical and horizontal surfaces. Material collected conforms well to the description of VAN NAME (1945).

Material examined. BRAZIL, Rio de Janeiro: Arraial do Cabo (Praia do Forno), 22 ${ }^{\circ} 57^{\prime} 36^{\prime \prime}$; ; 4204'19"W, 1 colony, 23.XI.2002, L. V. G. Costa col. (DZUP, CLA 01); (Saco do

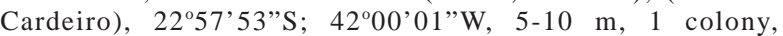
15.II.2003, L. V. G. Costa col. (DZUP, CLA 02); (Ilha de Cabo

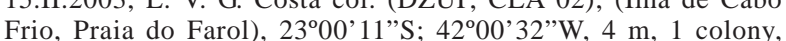
13.IV.1993, R. M. Rocha col. (DZUP, POLY 25).

Polycitoridae Michaelsen, 1904

\section{Cystodytes dellechiajei (Della Valle, 1877)}

This species was only found outside the bay of Arraial do Cabo, in the area under direct influence of the upwelling and lower water temperature. In the coast of São Paulo, this species was found only once, below $20 \mathrm{~m}$, where the waters are colder. These cold waters are due to the deeper ACAS (Central South Atlantic Waters) under the warm coastal waters, especially during the summer. Further south in the state of Paraná, $C$. dellechiajei also occurs in cold but shallow (1-3 m) waters. Features of this species concur with the description of F. MonNiot (1972).

Material examined. BRAZIL, Rio de Janeiro: Arraial do Cabo (Saco dos Ingleses), 2300'18'S; 42 00'27'W, 7-10 m, 1 colony, 10.IV.2001, R. M. Rocha col. (DZUP, CYS 01).

Polyclinidae Milne-Edwards, 1842

\section{Polyclinum constellatum Savigny, 1816}

The colonies are encrusting and dark green with white or beige stellate systems well visible on the colony surface. Colonies are $2.5-6.5 \mathrm{~cm}$ long and vary from $0.5-2.0 \mathrm{~cm}$ thick. In living colonies, the tunic is firm, cartilaginous and without sand on surface or inside the colony, although supporting encrusting organisms such as hydrozoans. The systems are circular and ramified, with about 20 zooids per system bordering the circular cloaca. The zooids are green, 7 $\mathrm{mm}$ long when relaxed, with white apertures, dorsal languets and, occasionally, the entire thorax. The oral siphon is tubular, fringed by six long and triangular lobes; both circular and longitudinal muscles are conspicuous. The large atrial siphon is circular, with a long or short, pointed or broad, dorsal languet with many diminute lobes. The languet displays slender bands of longitudinal muscles and the margin of the atrial siphon bears a band of circular muscles. A thin projection of the body lies posterior to the atrial aperture along the mid-dorsal line. Eight to eleven, usually nine, longitudinal muscle bands are found on each side of the thorax; they originate at the oral siphon or the dorsal languet and end in the middle of the thorax. Transversal muscles are absent in the thorax. Sixteen oral tentacles of two sizes occur in one circle in the base of the oral siphon. The prepharyngeal groove is double, slightly curved around the protruding dorsal tubercle which contains a small circular aperture. The pharynx presents 11 to 13 rows of stigmata, and those of the mid-thorax have between 15 and 18 stigmata on each side. Seven small papillae occur on the transverse bars on each side. The abdomen is short with the distal end of the esophagus bending at a right angle, leaving the stomach horizontal to the thorax. The stomach is globular with a smooth wall and the mid-intestine is short. The intestine is twisted and the bilobed anus ends between the seventh and the ninth rows of stigmata. Pyloric tubules were not visible. One long stoloniferous vessel arises from the posterior abdomen.

The posterior abdomen is sacular, with a long and thin neck that arises from the middle of the left side of the gut loop. The testis is formed by 14-20 round or pyriform follicles that occupy the entire gonadal sac. The ovary has 3-13 oocytes in the center of, or slightly anterior or posterior, to the gonadal sac. Usually two, but up to five embryos develop in the atrial cavity. The non-pigmented oval larva is $0.5 \mathrm{~mm}$ long, with the tail reaching halfway around the trunk. Three adhesive papillae in the mid-anterior line have long and thin peduncles and four pairs of clavate ectodermal ampullae. Many round small vesicles are found dorsally and ventrally near the tail. Both an ocellum and a statocyte are present.

Remarks. This species is widely spread in the Caribbean (VAn Name, 1945; F. Monniot, 1983a) but in the Southern and Southeastern Brazil it was only found on artificial substrates, rarely in few ports of the state of São Paulo and on buoys for mussel cultures in the State of Santa Catarina. These observations suggest that this species may have been introduced by ship transportation.

Material examined. BRAZIL, Rio de Janeiro: Arraial do Cabo (Ilha de Cabo Frio), 2300'07'S; 4200'19"W, < $1 \mathrm{~m}, 1$ colony, 09.I.2003, L. V. G. Costa col. (DZUP, POCN 01; permanent slide, POCL 1.85). 


\section{Polyclinum molle sp. nov.}

(Figs. 2-4)

Etymology. Latin, mollis = soft. The very soft consistency of the tunic suggested this name for the species.

The encrusting colonies are $4 \mathrm{~cm}$ long and $1.5 \mathrm{~cm}$ thick, found on vertical surfaces. Brown or golden while alive, some have a superficial red tint. Colonies preserved in formalin have transparent tunics containing beige or brown zooids. The tunic is very soft and without sand on surface, but the colony may have some sand and feces inside, close to the under surface. Zooids are uniformly spread around the entire surface without forming any distinguishable systems. Zooids (fig. 2) are transparent and slightly beige or brown, $4 \mathrm{~mm}$ long when well relaxed and thoraces are $2 \mathrm{~mm}$ long. The oral siphon is short and fringed by six long, triangular lobes; both circular and longitudinal muscles are conspicuous. The large atrial siphon is circular, with a dorsal languet that may be long or short, while usually very wide at the base. Up to eight small projections fringe the distal margin of the languet and slender bands of muscles parallel the languet. A band of circular muscles borders the margin of the atrial siphon. Posterior to the atrial aperture, on the mid-dorsal line, there is a very small projection of the body wall. Five to eight longitudinal muscle bands are found on each side of the thorax; they originate at the oral siphon or at the dorsal languet and end in the middle of the thorax. Transversal muscles are absent on the thorax. Oral tentacles occur in one circle at the base of the oral siphon, with 6-8 long, and about 12 short tentacles. The prepharyngeal groove is double, slightly curved around the protruding dorsal tubercle with a small circular aperture. There are 12 rows of stigmata with between 12 and 15 stigmata on each side of the ones in the middle of the thorax. Transverse vessels have thin muscle bands and 8 simple papillae on each side.

The abdomen is short. The distal end of the esophagus bends at a right angle, leaving the globular, smooth-walled stomach horizontal to the thorax. The intestine is twisted and the anus is bilobed, ending between the fifth and sixth rows of stigmata. The pyloric tubules were not visible. One long stoloniferous vessel arises from the posterior abdomen.

The posterior abdomen is sacular, with a long, thin neck arising from the middle of the left side of the gut loop. The testis is formed by 14 round or pyriform follicles; the ovary has up to four, either anterior or posterior, oocytes in the gonadal sac. Usually two, but up to five embryos, develop in the atrial cavity; a brood pouch is absent. The larva (fig. 3) is not pigmented, oval, $0.45 \mathrm{~mm}$ long, and the tail goes around $3 / 4$ of the trunk. There are three adhesive papillae in the mid-anterior line (fig.4), with long and thin peduncles. The 12 clavate ectodermic ampullae are distributed as folows: four short ones on each side and four long ones in the mid-anterior line between the adhesive papillae. There are many round small vesicles dorsally and ventrally near the tail. Both ocellum and statocyte are present.
Remarks. Besides $P$. constellatum, the only Polyclinum species registered from Brazil is $P$. brasiliense Michaelsen, 1923. The present species differs from $P$. brasiliense by the absence of systems in the colony, absence of sand on the surface, shorter zooids, fewer longitudinal muscular bands on the thorax, fewer oral tentacles, fewer lobes on the anus, and smaller larva (Michaelsen, 1923). Another species that resembles $P$. molle is Polyclinum aurantium Milne-Edwards, 1841, from which the present species differs by the absence of systems of zooids around a protruded cloaca (PÉRÈs, 1949), and the higher number of ectodermic ampullae in the larva (Millar, 1953).

Type material. Holotype, 1 colony and permanent slide, BRAZIL, Rio de Janeiro: Arraial do Cabo (Praia do Forno), 22 57'36"S; 42 04'19"W, 6 m, 09.V.2001, L. V. G. Costa col. (MZUSP 16245). Paratypes: Arraial do Cabo (Praia do Forno), 2257'36”'S; 4204'19”W, 6 m, 09.IV.2001, R. M. Rocha col. (DZUP, POCN 04); (Praia do Forno), 22 $57^{\prime} 36^{\prime \prime} \mathrm{S}$; 42 04'19"W, 2-5 m, 22.II.2003 (DZUP, POCN 06); (Saco do Gato), 22057'59"S; 4200'13"W, 19.I.2003, L. V. G. Costa col. (DZUP, POCN 02; permanent slide, POLY 1-83); (Ilha de Cabo Frio), 2300'07”S; 4200'19”'W, 1.II.2001, L. V. G. Costa col. (DZUP, POCN 05).

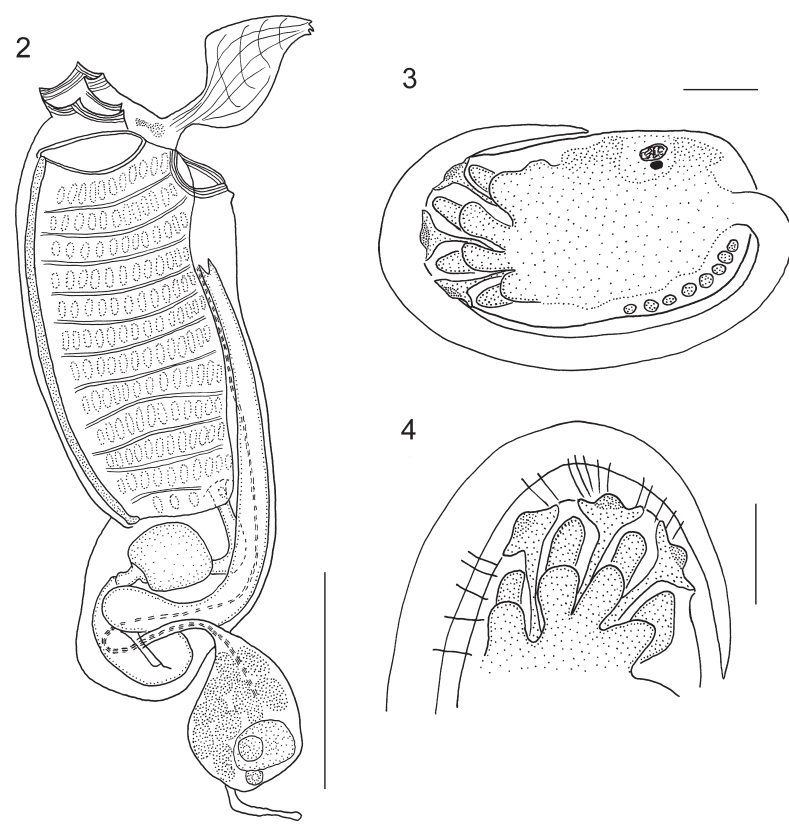

Figs. 2-4. Polyclinum molle sp. nov. 2, zooid; 3, larva; 4, detail of the anterior region of the larva. Scales: fig. 2, $1 \mathrm{~mm}$; figs. $3-4$, $100 \mu \mathrm{m}$.

Holozoidae Berril, 1950

\section{Distaplia bermudensis Van Name, 1902}

The colonies are greenish or bluish in formalin, measuring $3 \mathrm{~cm}$ in diameter, with a thickness that varies between $2-7 \mathrm{~mm}$. The tunic is of soft consistence and smooth, without any incrustations or associated organisms. The zooids are organized in circular systems with 8-14 individuals. The cloacal cavity is reduced and thoracic. The zooid is $1.5 \mathrm{~mm}$ long and presents a 
white pigmentation around the oral siphon and, sometimes, distributed on the body. The body wall is opaque, with conspicuous transverse muscles. The oral siphon is short and tubular, with a strong circular musculature, while the atrial aperture is wide with smooth margin. The prepharyngeal groove is double, the peritubercular area is rounded, and the dorsal tubercle aperture forms a very small circle. The pharynx has four rows of stigmata, with 15 to 17 per half row, the smaller of which are adjacent to the endostyle. The anterior area of the pharynx is not perforated. Transversal vessels are high and parastigmatic vessels are present.

The oesophagus is short and slightly curved at the distal end. The smooth stomach is oval shaped. The anus is bilobed ending between the 3rd and 4th row of stigmata. Two stoloniferous vessels are present. The rosete-shaped gonads are inside the intestinal loop. The testis has 8 round follicles and the ovary is centered inside the gut loop with 1-2 oocytes. The larval trunk is $1 \mathrm{~mm}$ long, oval, and the tail goes half-way around it. Three large adhesive papillae are present, whose peduncles have an enlarged base. Ectodermic ampullae are absent. Four rows of stigmata are visible on the larval pharyngeal sac. Both ocellum and statocyte are present.

Remarks. This is a common species in the Caribbean (VAN NAME, 1945; F. MonNiot, 1983b), also found in Southeastern and Southern Brazil (Espírito Santo - T. M. C. Lotufo, pers. comm.; São Paulo - RodRigues et al., 1998; Paraná - Rocha \& NASSER, 1998). Color polymorphism is characteristic of this species but all colonies turn greenish or bluish in formalin.

Material examined. BRAZIL, Rio de Janeiro: Arraial do Cabo (Praia do Forno), 22 ${ }^{\circ} 57^{\prime} 36^{\prime \prime} S$; 42 04'19”'W, 3-5m, 1 colony, 09.IV.2001, R. M. Rocha col. (DZUP, DIST 01); (Ilha de Cabo Frio, Praia do Farol), 2300'07"S; 42 00'19"W, 1 colony, 19.IV.2001, R. M. Rocha col. (DZUP, DIST 02).

Ascidiidae Herdmann, 1880

\section{Ascidia sydneiensis Stimpson, 1855}

This is a very common species in the southern hemisphere with records in the Atlantic (VAN NAME, 1945; Millar, 1958; C. Monniot, 1983a), Indian (Kott, 1985) and Pacific Ocean (ToKioKA, 1953; NishiKawA, 1991; KотT, 1985). The material agrees well with available descriptions and has all the diagnostic features mentioned by КотT (1985): position of transverse muscles forming a short border around the right side of the body, lobed anal border, position of the neural gland closely behind the dorsal tubercle, asymmetrical dorsal lamina, fringed siphon lobes, and a mud-distended gut.

Material examined. BRAZIL, Rio de Janeiro: Arraial do Cabo (Praia do Forno), 22 ${ }^{\circ} 57^{\prime} 36^{\prime}$ 'S ; 42 $04^{\prime} 19^{\prime \prime} \mathrm{W}, 1$ individual, 22.II.2003, L. V. G. Costa col. (DZUP, ASC 21).

\section{Phallusia nigra Savigny, 1816}

This species was reported by RodRigues et al. (1998) on the coast of the state of São Paulo. In Arraial do Cabo, Phallusia nigra is abundant on the rocky walls, in the zone of the anthozoan Palythoa caribaeorum (Duchassaing \&
Michelotti, 1860) from 1 to $7 \mathrm{~m}$ deep. This zoanthid is usually associated with sheltered environments (CASTRO et al., 1995), and the presence of $P$. nigra was restricted to the area between Cabo Frio Island and the continent. Since this species is very common and well-known, and found in all sites, only one voucher specimen was collected.

Material examined. BRAZIL, Rio de Janeiro: Arraial do Cabo (Praia do Forno), 2257'36"S; 42 04'19"W, 1 individual, 09.IV.2001, L. V. G. Costa col. (DZUP, PHA 01).

Styelidae Sluiter, 1895

\section{Botrylloides giganteum (Pérès, 1949)}

The encrusting colony is $2-5 \mathrm{~mm}$ thick, irregularly shaped, conforming to the surface of the substrate. It is brown, even in formalin. The transparent tunic is firm, fleshy, and smooth, revealing the linear systems of zooids. Zooids measure about $2 \mathrm{~mm}$ in length. The body wall is very delicate and transparent; longitudinal or circular musculature was absent. The smooth-margined oral siphon is round. The atrial siphon is large and the dorsal languet varies in shape and length. The long pharynx may have up to 14 rows of stigmata. The esophagus is short and very curved and the stomach is elongated with nine or ten longitudinal folds and a small ampullae-like gastric caecum at the pyloric region. The anus is slightly bilobed. One developing embryo is found on both sides of the body, within a more or less protruding brood pouch posterior to the testis. The testis has 8-15 oval follicles.

Remarks. The colony structure, color and zooid placement within the colony were as given by PéRÈs (1949). Zooids from Arraial do Cabo, however, are smaller and structures are fewer (oral tentacles, rows of stigmata, folds on the stomach wall), but within the range given by ARON \& SolÉ-CAva (1991). The voucher colony is rather thin but other colonies found in the region were as thick as 5 $\mathrm{mm}$. Despite the color polymorphism described for this species (RODRIGUES et al., 1998) only violet colonies were seen in Arraial do Cabo. The color is preserved in formalin.

Material examined. BRAZIL, Rio de Janeiro: Arraial do Cabo (Ilha de Cabo Frio, Praia do Farol), 2300'07'S; 4200'19'W, 1 colony, 25.VII.2000, L. V. G. Costa col. (DZUP, STY 78; permanent slide, STY 2.74); ditto, 1 colony, 28.VII.2000, L. V. G. Costa col. (DZUP, STY 76).

\section{Botrylloides nigrum Herdman, 1886}

Botrylloides nigrum has a wide geographical distribution (RoDRIGUES et al., 1998) and lives on a wide range of substrates, both natural and artificial. In Arraial do Cabo it has been observed on the pillars of the wharf and on rafts, at various depths.

Material examined. BRAZIL, Rio de Janeiro: Arraial do

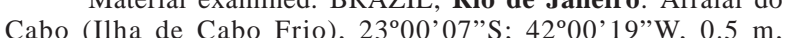
02.VII.2002, L. V. G. Costa col. (DZUP, BOTD 01).

\section{Symplegma brakenhielmi (Michaelsen, 1904)}

The colony is more transparent and less colored than S. rubra. This species can be easily distinguished from $S$. rubra by the swollen dorsal tubercle of the former, with a 
small circular aperture inside; by the two incomplete dorsal left longitudinal vessels, reaching the dorsal lamina at the level of the fourth and seventh rows of stigmata; by the fewer testis follicles; and by having only two tissue connections linking the caecum with the intestine. It is a very common species along the Brazilian coast.

Material examined. BRAZIL, Rio de Janeiro: Arraial do Cabo (Praia do Forno), 22 ${ }^{\circ} 57^{\prime} 36$ "'S; 4204'19”W, 22.II.2003, L. V. G. Costa col. (DZUP, SYMP 05).

\section{Symplegma rubra Monniot, 1972}

The colonies are formed by encrusting sheets up to $10 \mathrm{~cm}$ long and 2-3 mm thick. The wine-colored colony turns orange or cream in $10 \%$ formalin. The tunic is very thin and transparent. Zooids are 3-3.5 mm long and are not arranged in systems. Fourteen rows of stigmata are found along the dorsal lamina. The longitudinal vessels are complete, with four on each side; on the left side they are not parallel and the most dorsal vessel curves towards the dorsal lamina, terminating at the ninth row of stigmata while the second vessel ends at the tenth row. Twelve oral tentacles comprise two sizes. The prepharyngeal groove has a simple margin and continues dorsally, not forming a notable $\mathrm{V}$ around the dorsal tubercle which has a very small aperture. The stomach has 13 longitudinal folds and a pyloric caecum with three points of tissue connection with the intestine. The testis is multiply lobed: 3-7 anterior and 4-8 posterior lobes. The ovary contains 8-9 oocytes on each side of the body. Larvae were absent.

Remarks. The brilliant color of the colony, shape of the testicles, shape of the tubercular region and position of the left dorsal longitudinal vessels were used to identify this species. The wine color morph is by far the most abundant in the region, but yellow colonies may also occur; this contrasts strongly with the wide range of color morphs found in the state of São Paulo (Rodrigues et al., 1998).

Material examined. BRAZIL, Rio de Janeiro: Arraial do Cabo (Saco do Cherne), 22 ${ }^{\circ} 58^{\prime} 14^{\prime \prime S}$; 42 ${ }^{\circ} 01^{\prime} 02^{\prime \prime W}, 8-10 \mathrm{~m}$, 9.IV.2001, R. M. Rocha col. (DZUP, SYMP 04); (Pedra Vermelha), 22 59'18"S; 41 59'54"W, 8 m, 10.II.2003, L. V. G. Costa col. (DZUP, SYMP 07).

\section{Polyandrocarpa anguinea (Sluiter, 1898)}

The encrusting colony is small $(3.5 \times 2 \mathrm{~cm}), 1.3 \mathrm{~cm}$ thick, and light-brown in color. The colony completely loses its color in formalin and the specimen studied has no sand on the surface. The tunic has a leathery appearance but it is not very thick or resistant to tearing. Siphons are well protruded from the surface and marked by four lobes of the tunic. One medium zooid was $1 \mathrm{~cm}$ wide (siphon axis) and $0.5 \mathrm{~cm}$ high and dorsoventrally flattened. Both siphons are long and apical. The body wall is delicate and opaque, slightly yellow with orange siphons. Internally it is covered by very small projections, but no endocarps. Fifteen oral tentacles are of two sizes (9 large and 6 very small), rather distant from the prepharyngeal groove, which is simple and forms a pronounced $\mathrm{V}$ around the peritubercular area. The neural gland aperture is U-shaped. The pharynx has the usual four folds, three or four stigmata per mesh and parastigmatic vessels. The formula of the longitudinal vessels is: left side E $594124135101 \mathrm{LD}$; right side LD $112410412466 \mathrm{E}$. The dorsal lamina has a smooth edge and is larger towards the aperture of the esophagus where it ends. The globular or slightly oval stomach has about 14 internal longitudinal ridges, without a caecum. The first intestinal loop is large, without an endocarp. The anus is bilobed with the toothed margin of each lobe curving outward. Gonads were absent.

Remarks. The specimen can be identified by the color and shape of the colony and by the typical characteristics of the gut (shape of the stomach, absence of caecum and endocarp in the intestinal loop). Fewer oral tentacles were found than in the figures in RODRIGUES (1977), but, since the colony is small and without gonads, we assume that the zooids may grow and develop more tentacles. The number of gastric folds is also close to the lower value of the range presented by this species: 12 20 (RodRIGUES, 1977).

Material examined. BRAZIL, Rio de Janeiro: Arraial do Cabo (Saco do Cherne), 22 $58^{\prime} 14$ "'S; 4201'02”W, 7 m, 1 colony, 09.IV.2001, R. M. Rocha col. (DZUP, PODC 02); (Saco do

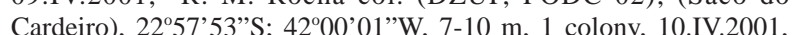
R. M. Rocha col. (DZUP, PODC 01).

\section{Eusynstyela floridana (Van Name, 1921)}

The only colony collected was encrusting an area of about $2 \mathrm{~cm}^{2}$, orange in nature, completely colorless in $10 \%$ formalin. Zooids are $6 \mathrm{~mm}$ long and not densely arranged within the colony, united only by the basal membrane. The opaque body wall is delicate with few muscle bands. Both siphons are smooth-margined with very conspicuous circular muscles, forming a dense layer at the base. Eleven oral tentacles are of three sizes. Tentacles are absent in the atrial siphon. The prepharyngeal groove is simple and forms a deep $\mathrm{V}$ around the peritubercle area; the dorsal tubercle aperture is a vertical cleft. The dorsal lamina has a smooth margin. One example of longitudinal vessels formula is E 16310 $373150 \mathrm{DL}$ on the right, and DL $01037210391 \mathrm{E}$ on the left. Parastigmatic vessels are absent. The globular stomach has 13 longitudinal internal folds, and a short caecum at the pyloric end. The primary intestinal loop is closed and the secondary is very short, placing the bilobed anus very close to the esophageal aperture. Gonads are few, five or six on each side. The two testicular follicles are adjacent to the body wall and the many oocytes are beside the atrial cavity, in the same arrangement described by C. MonNIOT (1983b). Brooding larvae were absent.

Remarks. This species has been recorded from São Paulo (Rodrigues et al., 1998) and the Caribbean (C. MonNIOT, 1983b) and hence it was not surprising to find it in Rio de Janeiro. The specimen differs from Guadeloupe and São Paulo specimens in the living color, which is not wine with a marked light stain between the siphons, smaller number of oral tentacles and gonads, but the position and aspect of the gonads are very similar to those described by C. MONNIOT (1983b). 
Material examined. BRAZIL, Rio de Janeiro: Arraial do

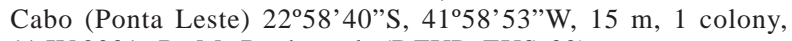
11.IV.2001, R. M. Rocha col. (DZUP, EUS 02).

\section{Eusynstyela tincta (Van Name, 1902)}

The encrusting colony is usually on the undersurface of rocks, $4 \mathrm{~mm}$ thick, covering about 6 $\mathrm{cm}^{2}$. The colony is red in the field, but completely colorless in 10\% formalin. Zooids are longer (maximum length $1.3 \mathrm{~cm}$ ) than wide. The body wall is delicate, opaque, with very few muscle bands. The siphons have a smooth fringe and a band of circular musculature close to the aperture. Both are lined internally by a vellum with short filiform projections. There are 19 oral tentacles of three or four sizes, depending on the individual. The atrial siphon is encircled by very short and slender tentacles. The prepharyngeal groove is simple and forms a deep V around the rounded aperture of the dorsal tubercle. One of the individuals had two apertures, one of which was deeply within the V. The dorsal lamina has a smooth margin. One example of the longitudinal vessel formula is E $0417161100 \mathrm{LD}$ on the right; LD $071518150 \mathrm{E}$ on the left side. Parastigmatic vessels are present. The tubular stomach is long with 12 longitudinal internal folds. A short caecum is found at the pyloric end and is slightly curved, having three connections with the intestine. The primary intestinal loop is closed and the secondary is very short. The anus is not lobed. Gonads are few with three or four on each side and are very difficult to remove from the pockets in which they lie within the tunic. Testicular follicles are oriented towards the body wall and the many oocytes towards the atrial cavity. Brooding larvae were absent.

Remarks. The species has been reported from São Paulo (RodRigues et al., 1998) and the Caribbean (VAN NAme, 1945; Van Der Sloot, 1969; C. Monniot, 1983b), hence it was not surprising to find it in Rio de Janeiro. The specimen differs from those from Guadeloupe in the larger number of oral tentacles (25-30) and of gonads (up to eight on each side) in the latter. C. MоNNIOT (1983b) did not mention the small filiform projections seen on the inner lining of the siphons.

Material examined. BRAZIL, Rio de Janeiro: Arraial do Cabo (Saco do Cardeiro), 22 $2^{\circ} 57^{\prime} 53^{\prime \prime} \mathrm{S}$; 42 00 '01”W, 7-9 m, 10.IV.2001, R. M. Rocha col. (DZUP, EUS 01).

\section{Styela plicata (Lesueur, 1823)}

This species has a wide geographical distribution (VAn NAME, 1945; Millar, 1958; Rodrigues et al., 1998) and it appears in the list of the most common nonindigenous ascidians in the world, usually very abundant in port areas (LAMBert, 2001). In Arraial do Cabo, Styela plicata was usually found on wharf pillars and forming large aggregates. Farther south, in the state of Santa Catarina, it recruits in high densities on submerged structures of hanging mussel and oyster cultures.

Material examined. BRAZIL, Rio de Janeiro: Arraial do Cabo (Praia dos Anjos, Harbor), 22 $2^{\circ} 58^{\prime} 43^{\prime \prime} \mathrm{S} ; 2^{\circ} 01^{\prime} 58^{\prime \prime} \mathrm{W}, 2 \mathrm{~m}$, 28.VII.2000, L. V. G. Costa col. (DZUP, STY 77).
Pyuridae Hartmeyer, 1908

Herdmania pallida (Heller, 1878)

This simple ascidian is usually found on rocky walls, it is almost round and $4.0 \mathrm{~cm}$ in diameter. In $10 \%$ formalin the color is beige and the tunic can be very encrusted with algae and other sessile invertebrates. The siphons are close to each other, both with smooth margin. The acicular spicules of the body wall concentrate mainly between the siphons and in the ventral region. There are up to 15 wide and branched oral tentacles. The prepharyngeal groove has a double margin and forms a deep $\mathrm{V}$ around the dorsal tubercle, whose aperture is horseshoe-shaped with spiraled ends. The dorsal lamina is subdivided into several thin languets. The pharynx has eight folds on each side of the body, with longitudinal vessels that vary from $8-15$ on each folds. Parastigmatic vessels are present. The esophagus is short and the digestive gland of the stomach has a small portion on the right side and a larger portion on the left side of the stomach. The intestine is attached to the body wall with a closed primary loop and an open and small secondary loop. The anus is slightly lobed. The gonad on the right side is ventral.

Remarks. This species was previously recorded from the state of São Paulo (Rodrigues et al., 1998) as Herdmania momus (Savigny, 1816). The genus was recently reviewed (KotT, 2002; MonNiot, 2002; NishiKawa, 2002) and the authors concluded that the Atlantic species is H. pallida (Heller, 1878). The main difference between these species is the unique opening of the sperm duct in $H$. pallida whereas H. momus has various apertures along the sperm duct. The former character was observed in specimens from Arraial do Cabo, confirming the identification.

Material examined. BRAZIL, Rio de Janeiro: Arraial do Cabo (Praia do Forno), 2257'36”'S; 4204'19”W, 09.IV.2001, R. M. Rocha col. (DZUP, HER 01); (Saco do Cardeiro), 22 57 '53"S; $42^{\circ} 00$ '01”W, 10.IV.2001, R. M. Rocha col. (DZUP, HER 02).

\section{Microcosmus exasperatus Heller, 1878}

This species was recorded by RoDRIGUES et al. (1998) on the coast of São Paulo and by ROCHA \& NASSER (1998) in the state of Paraná. In Arraial do Cabo it forms important aggregates with many epibionts (barnacles, filamentous macroalgae, hydrozoans, polychaetes and arborescent bryozoans) on the tunic, which apparently enhances the camouflage of the animals. It is one of the most abundant ascidians between 5-15 $\mathrm{m}$ deep in the area.

Material examined. BRAZIL, Rio de Janeiro: Arraial do Cabo (Praia do Forno), 22 ${ }^{\circ} 57^{\prime} 36^{\prime \prime S}$; 42 04'19”W, 23.XI.2002, L. V. G. Costa col. (DZUP, MIC 03); (Saco do Cardeiro), 22 ${ }^{\circ} 57$ '53"S; 42 00'01"W, 5-10 m, 15.II.2003, L. V. G. Costa col. (DZUP, MIC

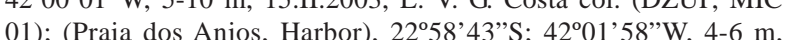
11.IV.2001, R. M. Rocha col. (DZUP, MIC 02).

\section{DISCUSSION}

Most species at Arraial do Cabo are common and have been collected further south in São Paulo (RodRIGUES et al., 1998). Some are widely distributed in the three major 
oceans, e.g. Symplegma brakenhielmi, S. rubra, Styela plicata, Polyandrocarpa anguinea and Microcosmus exasperatus, and are considered traveling species that disperse by ship transportation (LAMBERT, 2001). The Praia dos Anjos in Arraial do Cabo has a harbor (50 year old) with low traffic, which receives domestic cargo from salt industries and serves suppliers for oil exploration from Bacia de Campos. Oil platforms were built in other countries and shipped to Brazil and so could have brought species to the Rio de Janeiro coast at that time. After the first arrival to the Brazilian coast, domestic ship transportation could be responsible for spreading the introduced species to other points along the coast.

The family Didemnidae contributed about half the ascidian fauna in this collection, but due to its complexity is still being analyzed (to be presented in another paper). Even considering didemnids, the low richness of ascidian species in this area is remarkable. Due to its more tropical location and the influence of upwelling, a greater species richness would be expected. This contrasts with the more southern São Sebastião region in São Paulo (RodRigues et al., 1998), where around 50 species have been recorded. The collecting effort consisted of an intensive one-week survey in April 2001 and scattered dives from 2000 to 2003, while collecting effort in São Paulo lasted from 1985 to 1995, concentrated within the last two years. This could explain the greater richness in São Paulo, together with the fact that São Sebastião is subject to the influence of an important port with international traffic that may bring many foreign species to the region.

It is also worth noting that this fauna in characteristically tropical and most species are also known from the Caribbean (tab. I). The idea of an impoverished Caribbean fauna mentioned by Rodrigues \& Rocha (1993) regarding the coast of São Paulo also applies to Arraial

Table I. North - Southern distribution of ascidian species along the West Atlantic according to the literature ${ }^{1}$ and the present study. Species with? were not positively identified by the author.

\begin{tabular}{|c|c|c|c|c|}
\hline & Caribbean & NE Brazil & RJ & SP \\
\hline Clavelina oblonga & $\mathrm{x}$ & $?$ & $\mathrm{X}$ & $\mathrm{x}$ \\
\hline Cystodytes dellechiajei & $\mathrm{x}$ & $\mathrm{X}$ & $\mathrm{x}$ & $\mathrm{x}$ \\
\hline Distaplia bermudensis & $\mathrm{x}$ & $\mathrm{x}$ & $\mathrm{x}$ & $\mathrm{x}$ \\
\hline Polyclinum constellatum & $\mathrm{x}$ & & $\mathrm{x}$ & $\mathrm{x}$ \\
\hline Polyclinum molle sp. nov. & & & $\mathrm{x}$ & \\
\hline Ascidia sydneiensis & $\mathrm{x}$ & & $\mathrm{x}$ & $\mathrm{x}$ \\
\hline Phallusia nigra & $\mathrm{x}$ & & $\mathrm{x}$ & $\mathrm{x}$ \\
\hline Botrylloides giganteum & & & $\mathrm{x}$ & $\mathrm{x}$ \\
\hline Botrylloides nigrum & $\mathrm{x}$ & $\mathrm{x}$ & $\mathrm{x}$ & \\
\hline Symplegma brakenhielmi & $\mathrm{x}$ & $?$ & $\mathrm{x}$ & $\mathrm{x}$ \\
\hline Symplegma rubra & $\mathrm{x}$ & $\mathrm{x}$ & $\mathrm{x}$ & \\
\hline Polyandrocarpa anguinea & $\mathrm{x}$ & & $\mathrm{x}$ & $\mathrm{x}$ \\
\hline Eusynstyela floridana & $\mathrm{x}$ & & $\mathrm{x}$ & $\mathrm{x}$ \\
\hline Eusynstyela tincta & $\mathrm{x}$ & $\mathrm{x}$ & $\mathrm{x}$ & \\
\hline Styela plicata & $\mathrm{x}$ & & $\mathrm{x}$ & $\mathrm{x}$ \\
\hline Herdmania pallida & $\mathrm{x}$ & $\mathrm{x}$ & $\mathrm{x}$ & $\mathrm{x}$ \\
\hline Microcosmus exasperatus & $\mathrm{x}$ & $\mathrm{x}$ & $\mathrm{x}$ & $\mathrm{x}$ \\
\hline
\end{tabular}

${ }^{1}$ Caribbean (VAn Name, 1921, 1945; Millar, 1962, 1978; VAn DER Sloot, 1969; Millar \& Goodbody, 1974; Monniot, C. 1983a, b, c; Monniot \& Monniot, 1984; Monniot, F. 1983a, b; GoodBody, 1984a, b, 1993, 1995, 1996, 2003; GoodBody \& Cole, 1987); NE Brazil, northeastern coast of Brazil (Millar, 1977); RJ, State of Rio de Janeiro (present work); SP State of São Paulo (VAn NAME, 1945; BJörnBerg, 1956; Millar, 1958; Rodrigues, 1962, 1977; Rocha \& MonNiot, 1993, 1995; Rodrigues \& Rocha, 1993; Rodrigues et al., 1998). do Cabo. A recent literature survey revealed 130 ascidian species recorded from the Caribbean, while a short 10day survey of ascidians at Bocas del Toro, on the Caribbean coast of Panamá, resulted in 58 species (R. M. Rocha, S. B. Faria \& T. R. Moreno, unpublished data). The only Arraial do Cabo species which does not occur in the Caribbean, Botrylloides giganteum, is known from tropical Africa (PÉRÈs, 1949).

Surveys in many different areas of southeastern Brazil are urgently needed to elucidate the geographical distribution of ascidians and to establish the environmental conditions that are associated with patchy distribution and relatively low diversity in this group.

Acknowledgments. To IEAPM (Instituto de Estudos do Mar Almirante Paulo Moreira) and Benthos Lab of the Universidade Federal do Rio de Janeiro for logistical support, Dr. Roberto Berlinck for dive support, Dr. James J. Roper for the English text correction, two anonymous reviewers for improvement of the manuscript, and $\mathrm{CNPq}$ for the research grant to RMR (process 300671/93-8).

\section{REFERENCES}

Aron, S. \& Solé-Cava, A. 1991. Genetic evaluation of the taxonomic status of two varieties of the cosmopolitan ascidian Botryllus niger (Ascidiacea: Botryllidae). Biochemical Systematics and Ecology, 19(4):271-276.

BJöRnBERG, T. K. S. 1956. Ascídias da costa sul do Brasil (nota prévia). Ciência \& Cultura, 8(3):164-165.

Castro, C. B.; Echeverría, C. A.; Pires, D. O.; Mascarenhas, B. J. A. \& Freitas, S. G. 1995. Distribuição de Cnidaria e Echinodermata no infralitoral de costões rochosos de Arraial do Cabo, Rio de Janeiro, Brasil. Revista Brasileira de Biologia, 55(3):471-480.

Costa, H. R. 1969a. Notas sobre os Ascidiacea brasileiros. I. Família Polyclinidae. Atas da Sociedade de Biologia do Rio de Janeiro, 12(4):191-195.

. 1969b. Notas sobre os Ascidiacea brasileiros. II. Família Didemnidae. Atas da Sociedade de Biologia do Rio de Janeiro, 12(4):201-203.

__. 1969c. Notas sobre os Ascidiacea brasileiros. III. Família Polycitoridae Michaelsen, 1904. Atas da Sociedade de Biologia do Rio de Janeiro, 12(5-6):277-279.

1969d. Notas sobre os Ascidiacea brasileiros. IV. Ordem Phlebobranchia (Lahille, 1887). Atas da Sociedade de Biologia do Rio de Janeiro, 12(5-6):289-292.

. 1969e. Notas sobre os Ascidiacea brasileiros. V. Subclasse Pleurogona. Atas da Sociedade de Biologia do Rio de Janeiro, Rio de Janeiro, 12(5-6):299-302.

_. 1969f. Notas sobre os Ascidiacea brasileiros. VI. Atas da Sociedade de Biologia do Rio de Janeiro, 12(5-6):321-325.

Godoy, E. A. S. \& Coutinho, R. 2002. Can artificial beds of plastic mimics compensate for seasonal absence of natural beds of Sargassum furcatum? ICES Journal of Marine Science, 59:111-115.

GoodBody, I. 1984a. The ascidian fauna of two contrasting lagoons in the Netherlands Antilles: Piscadera Baai, Curacao, and the Lac of Bonaire. Studies of fauna of Curacao and other Caribbean Islands, 67(202):21-61.

. 1984b. Ascidians from Caribbean shallow water localities. Studies of fauna of Curacao and other Caribbean Islands, 67(203):62-76.

. 1993. The ascidian fauna of a Jamaican lagoon: Thirty years of change. Revista de Biologia Tropical, Suplemento, 41(10):35-38.

_. 1995. Ascidian communities in Southern Belize - a problem in diversity and conservation. Aquatic Conservation, 5:355-358. 1996. Pycnoclavella belizeana, a new species of ascidian from the Caribbean. Bulletin of Marine Science, 58(2):590-597. . 2003. The ascidian fauna of Port Royal, Jamaica - I. Harbor and mangrove dwelling species. Bulletin of Marine 
Science, 73:457-476.

Goodbody, I. \& Cole, L. 1987. A new species of Perophora (Ascidiacea) from western Atlantic, including observations on muscle action in related species. Bulletin of Marine Science, 40(2):246-254.

Kотт, P. 1985. The Australian Ascidiacea part 1, Phlebobranchia and Stolidobranchia. Memoirs of the Queensland Museum, 23:1-440.

. 2002. The genus Herdmania Lahille, 1888 (Tunicata, Ascidiacea) in Australian waters. Zoological Journal of the Linnean Society, 134:359-374.

LAmbert, G. 2001. A global overview of ascidian introductions and their possible impact on the endemic fauna. In: SAWADA, H.; Yokosawa, H. \& Lambert, C. C. eds. The Biology of Ascidians. Tokyo, Springer Verlag. p.249-257.

Michaelsen, W. 1923. Neue und altbekannte Ascidien aus dem Reichsmuseum zu Stockholm. Mitteillungen aus dem Zoologischen Statsinstitut und Zoologischen Museum, 40:1-60.

Millar, R. H. 1953. On the collection of ascidians from the Gold Coast. Proceedings of the Zoological Society of London, 123(2):277-325. - 1958. Some ascidians from Brazil. Annals and Magazine of Natural History, 13:497-514.

1962. Some ascidians from the Caribbean. Studies of fauna of Curacao and other Caribbean Islands, 13(59):61-77.

1977. Ascidians (Tunicata: Ascidiacea) from the northern and northern-eastern Brazilian shelf. Journal of Natural History, 11(2): 169-223.

1978. Ascidians from the Guyana shelf. Netherlands Journal of Sea Research, 12(1):99-106.

Millar, R. H. \& Goodbody, I. 1974. New species of Ascidians from the West Indies. Studies of fauna of Curacao and other Caribbean Islands, 45:142-161.

Monniot, C. 1983a. Ascidies littorales de Guadeloupe 2. Phlebobranches. Bulletin du Muséum National d'Histoire Naturelle, ser. 4, A, 5(1):51-71.

1983b. Ascidies littorales de Guadeloupe. 4. Styelidae. Bulletin du Muséum National d'Histoire Naturelle, ser. 4, A, 5(2):423-456.

. 1983c. Ascidies littorales de Guadeloupe 6. Pyuridae et Molgulidae. Bulletin du Muséum National d'Histoire Naturelle, ser. 4, A, 5(4):1021-1044.

2002. Stolidobranch ascidians from the tropical western Indian ocean. Zoological Journal of the Linnean Society, 135:65-120.

Monniot, C. \& Monniot, F. 1984. Ascidies littorales de Guadeloupe. 7. Espèces nouvelles et complementaries a 1'inventaire. Bulletin du Muséum National d'Histoire Naturelle, ser. 4, A, 6(3):567-582.

Monniot, F. 1972. Ascidies Aplousobranches des Bermudes. Polyclinidae et Polycitoridae. Bulletin du Muséum National d'Histoire Naturelle, ser. 3, 82:949-962. .1983a. Ascidies littorales de Guadeloupe 3. Polyclinidae.
Bulletin du Muséum National d'Histoire Naturelle, ser. 4, A, 5(2):413-422.

.1983b. Ascidies littorales de Guadeloupe 5. Polycitoridae. Bulletin du Muséum National d'Histoire Naturelle, ser. 4, A, 5(4):999-1019.

Nishikawa, T. 1991. The ascidians of the Japan Sea 2. Publication of the Seto Marine Biological Laboratory, 35(1/3):25-170.

2002. Revision of the ascidian genus Herdmania (Urochordata: Ascidiacea) inhabiting Japanese waters. Species Diversity, 7(3):217-250.

Pérès, J. M. 1949. Contribution à l'étude des Ascidies de la côte occidentale d'Afrique. Bulletin de I'Institut Français d'Afrique Noire, 11(1-2):159-207.

Rocha, R.M. \& Monniot, F. 1993. Didemnum rodriguesi $\mathrm{sp.}$ nov. - a new didemnid ascidian common to southeastern Brazil and New Caledonia Annales de l'Institut Oceanographique, 69(2):261-265.

1995. Taxonomic and ecological notes on some Didemnum species (Ascidiacea, Didemnidae) from São Sebastião channel, south - eastern Brazil. Revista Brasileira de Biologia, 55:639-649.

Rocha, R.M. \& Nasser, C. M. 1998. Some ascidians (Tunicata, Ascidiacea) from Paraná State, Southern Brasil. Revista Brasileira de Zoologia, 15(3):633-642.

Rodrigues, S. A. 1962. Algumas ascídias do litoral sul do Brasil. Boletim da Faculdade de Filosofia Ciências e Letras da Universidade de São Paulo, ser. bot., 24:193-216. 1977. Notes on Brazilian ascidians. II. On the records of Polyandrocarpa anguinea (sluiter) e Polyandrocarpa maxima (sluiter). Revista Brasileira de Biologia, 37(4):721-726.

Rodrigues, S. A. \& Rocha, R. M. 1993. Littoral compound ascidians (tunicata) from São Sebastião, estado de São Paulo, Brazil. Proceedings of the Biological Society of Washington, 106:728-739.

Rodrigues, S. A.; Lotufo, T. M. C. \& Rocha, R. M. 1999. Ascidiacea. In: Migotto, A. E. \& Tiago, C. G. eds. BIOTASP - Invertebrados Marinhos. Vol. 3. São Paulo, FAPESP. p. 285-292.

Rodrigues, S. A.; Rocha, R. M. \& Lotufo, T. M. C. 1998. Guia ilustrado para identificação das ascídias do estado de São Paulo. São Paulo, Fapesp, Parma. 190p.

Токіока, T. 1953. Ascidians of Sagami Bay. Iwanami Shoten, Tokyo. $315 \mathrm{p}$.

Valentin, J. L. 1994. Ressurgência: fonte de vida dos oceanos. Ciência Hoje, 18(102):9-25.

VAN DER SLoot, C. J. 1969. Ascidians of the family Styelidae from the Caribbean. Studies of fauna of Curacao and other Caribbean Islands, 110:1-57.

VAN NAme, W. G. 1921. Ascidians of the West Indian region and southeastern United States. Bulletin of the American Museum of Natural History, 44:283-494.

1945. The North and South American ascidians. Bulletin of the American Museum of Natural History, 84:1-476.

Recebido em junho de 2004. Aceito em janeiro de 2005. ISSN 0073-4721

Artigo disponível em: www.scielo.br/isz

Iheringia, Sér. Zool., Porto Alegre, 95(1):57-64, 30 de março de 2005 